\title{
A FOURTH RECORD OF THE MEXICAN SULFUR BUTTERFLY, EUREMA MEXICANA, FROM MANITOBA
}

\author{
by John H. Masters, P.O. Box 7511, St. Paul, Minnesota
}

On July 4, 1968, when I was driving through Riding Mountain, Manitoba with Patrick J. Conway of Aledo, Illinois, Pat spotted what appeared to be an unusual butterfly and jumped out of the car to discover a worn female of The Mexican Sulfur, Eurema mexicana (Boisduval). This is only the fourth record of the occurrence of this species in Manitoba. The range of Eurema mexicana is normally from Central America and Mexico north to Arizona and Okiahoma; how. ever northward strays are sometimes taken, records being available from Nebraska, North Dakota, Saskatchewan, Ontario, Minnesota and Wisconsin, as well as Manitoba. Naturally the farther north one goes the scarcer records become and there have been only three previous records from Manitoba and only one from Saskatchewan-all of them many years ago.

Brodie (1929) cited two Manitoba examples of Eurema mexicana, from Aweme (Norman Criddle presumably the collector) and from Cartwright (presumably collected by E. F. Heath, although not listed from his collection by Wolley Dod, 1916). The third Manitoba record was recorded from Stonewall by Brooks (1942)! no additional details of this record can be obtained. Rev. Ronald R. Hooper of Fort Qu'Appelle reports only one known record from Saskatchewan, that one having been taken by his brother, Donald Hooper, at Somme.

Eurema mexicana is readily distinguished and cannot be confused with any other North American species. The forewing is basally white and the hindwing basally yellow with orange shading. Black borders are broad and on the forewing outline a "doghead" pattern similar to that in the Dogface
Butterfly, Colias cesonia (Stoll). The hindwing is squared off producing a short tail.

\section{LITERATURE CITED}

Brodie, H. J. 1929. A preliminary list of th Lepidoptera of Manitoba. Trans. Royal Canadian Inst. $17: 81-101$.

Brooks, G. S., 1942. A revised check list of the butterflies of Manitoba. Canadian Ent. $74: 31-36$.

Wolley Dod, F. H. 1916. The Heath collection of Lepidoptera. Canadian Ent. 48:161-167.

\section{SNAKE NOTES}

Mr. F. Skertchly, Box 292, Souris Manitoba, reports that snakes of three species have occurred on the banks of Plum Creek which flows through his land. Judging by his descriptions these are the Red-bellied Snake, Smooth Green Snake, and probably the Western Plains Garter Snake. As mentioned by Mr. Skertchly, the latter species tends to be more aggressive than other garter snakes. Good de scriptions of these reptiles are available in a booklet published by the Saskatchewan Museum of Natura History: A Guide to the Amphibians and Reptiles of Saskatchewan, by Francis Cook (1966, 40 pp.) This i: carried by the Blue Jay Bookshop Box 1121, Regina.-The Editors.

"When we lose the richness anc variety of scenery and wild plant anc animal communities anywhere, are we not that much poorer? Have we no also, along with the loss, taken a ster downward towards a monotypic typ of living which is not pleasant tc think about?" - quoted from Valle. of the Beavers, a nature trail in th Cypress Hills. 